\title{
PEMANFAATAN AUGMENTED REALITY SEBAGAI MEDIA PENGENALAN FLORA KHAS BENGKULU DENGAN METODE SINGLE MARKER BERBASIS ANDROID
}

\author{
Diana $^{1}$, Alandika Dwi Rama ${ }^{2}$, Rosa Fitriasari $\mathrm{Asa}^{3}$ \\ ${ }^{1,2,3}$ Program Studi Teknik Informatika Fakultas Teknik Universitas Muhammadiyah Bengkulu 2019 \\ Jalan Bali, PO Box 118, Bengkulu 38119 Telp. 0736-22765, fax. 26161 \\ ${ }^{1}$ Diana@umb.ac.id \\ ${ }^{2}$ dikakiting1818@gmail.com \\ ${ }^{3}$ rosafitriasariasa@gmail.com
}

\begin{abstract}
Abstrak: Kekayaan alam yang terdapat di Provinsi Bengkulu adalah flora khas yaitu Bunga Rafflesia dan Bunga Bangkai. Bunga Refflesia dan Bunga Bangkai banyak ditemui di Provinsi Bengkulu dan merupakan ikon dari Provinsi Bengkulu. Akan tetapi perhatian masyarakat hanya sampai menjadi ikon dan lambang, sedangkan upaya konservasinya hampir dikatakan sangat minim. Kurangnya perhatian ini menjadi hal yang sangat mengkhawatirkan karena sebagian besar jenis-jenis Rafflesia dan Bunga Bangkai digolongkan ke dalam kategori terancam. Dengan memperhatikan hal tersebut, perlu adanya alternatif media untuk memudahkan akses bagi masyarakat mendapatkan informasi lengkap tentang Bunga Rafflesia dan Bunga Bangkai dan dapat diselesaikan dengan adanya sebuah aplikasi pengenalan Bunga Rafflesia Bunga Rafflesia dan Bunga Bangkai dengan memanfaatkan teknologi augmented reality dengan platform android yang sangat popular pada masa kini.

Kata Kunci: Augmented Reality, Rafflesia Arnoldi, Bangkai, Single Marker, Android
\end{abstract}

Abstract: The natural treasure found in Bengkulu Province is peculiar flora, namely Rafflesia Flower and Bangkai Flower. Refflesia Flower and Bangkai Flower are mostly discovered in Bengkulu Province and become an icon of Bengkulu Province. However, people's attention is only to become an icon and symbol, while conservation efforts are almost said to be nethermost. This lack of concern is very disconcerted because most types of Rafflesia and Bangkai are classified as threatened. With that interest, it is necessary to have alternative media to facilitate access for the public to get detail information about Rafflesia Flowers and Bangkai Flower and can be completed by introducing an application of Rafflesia Flower Rafflesia and Bangkai Flower by utilizing augmented reality technology with the very popular android platform on present time.

Keywords: Augmented Reality, Rafflesia Arnoldii, Bangkai, Single Marker, Android

\section{Pendahuluan}

Provinsi Bengkulu merupakan provinsi di Indonesia yang terletak di Pulau Sumatera. Provinsi Bengkulu memiliki keanekaragaman adat istiadat, bangunan bersejarah, budaya maupun kekayaan alam. Kekayaan alam yang terdapat di Provinsi Bengkulu adalah flora khas Bunga Rafflesia dan Bunga Bangkai. Bunga Rafflesia adalah salah satu tumbuhan dengan sifat unik karena jenis ini hanya berupa kuncup atau bunga mekar, tidak ada batang, daun, dan akar. Rafflesia hanya dilengkapi haustorium, jaringan yang mempunyai fungsi mirip akar yang mengisap sari makanan hasil fotosintesa dari tumbuhan inang [1].

Selain Bunga Rafflesia, di Provinsi Bengkulu juga terdapat Bunga Bangkai. Bunga bangkai memiliki batang yang menjulang sehingga bunganya tidak menempel dengan permukaan tanah. Saat mekar, bunga bangkai terlihat seperti bunga terompet dengan bagian tengah yang lebih tinggi di banding bagian kelopaknya.

Bunga Refflesia dan Bunga Bangkai banyak ditemui di Provinsi Bengkulu dan merupakan ikon dari Provinsi 
Bengkulu. Akan tetapi perhatian masyarakat hanya sampai menjadi ikon dan lambang, sedangkan upaya konservasinya hampir dikatakan sangat minim. Kurangnya perhatian ini menjadi hal yang sangat mengkhawatirkan karena sebagian besar jenis-jenis Rafflesia dan Bunga Bangkai digolongkan ke dalam kategori terancam. Dengan kondisi seperti di atas, informasi yang sangat minim kepada masyarakat tentang Rafflesia dan Bunga Bangkai juga menjadi faktor bunga tersebut sedang menuju proses kepunahan.

Permasalahan diatas dapat diselesaikan dengan adanya sebuah aplikasi pengenalan Bunga Rafflesia dan Bunga Bangkai dengan memanfaatkan teknologi augmented reality dengan platform android yang sangat popular pada masa kini. Augmented Reality adalah teknologi yang menggabungkan obyek-obyek maya yang ada dan dihasilkan (generated) oleh komputer dengan benda-benda yang ada di dunia nyata sekitar kita [2].

Berdasarkan uraian yang telah dipaparkan di atas, maka kami mengambil judul penelitian yaitu "Pemanfaatan Augmented Reality Sebagai Media Pengenalan Flora Khas Bengkulu Dengan Metode Single Marker Berbasis Android".

\section{METODE PENELITIAN}

\section{A. Model Pengembangan Sistem RAD}

Model pengembangan sistem yang akan digunakan dalam penelitian ini adalah model Rapid Application Development (RAD). RAD adalah model proses pembangunan perangkat lunak yang incremental. RAD menekankan pada siklus pembangunan yang pendek/singkat. RAD mengadopsi model waterfall dan pembangunan dalam waktu singkat dicapai dengan menerapkan component based construction [3].

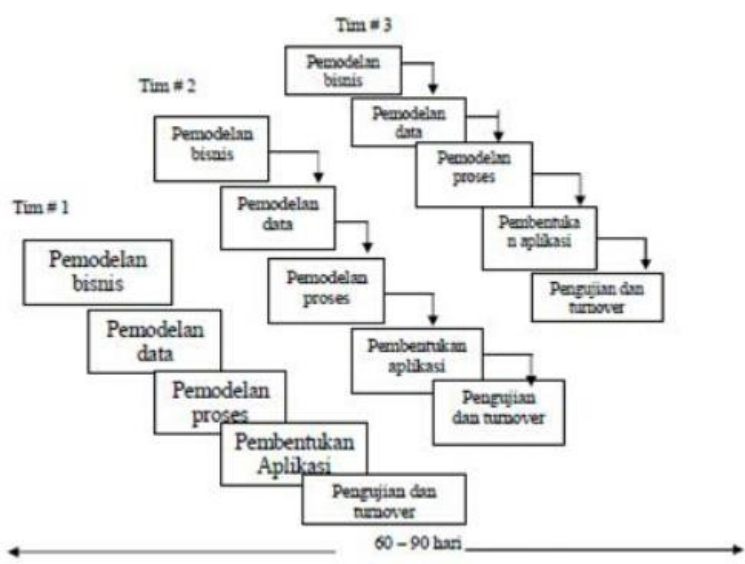

Gambar 1. Model RAD

Sukamto, R. A., and M. Shalahudin Rekayasa Perangkat Lunak. "Bandung." Informatika (2016).

\section{B. Augmented Reality}

Secara umum, Augmented Reality (AR) adalah suatu teknologi yang menggabungkan benda maya dua dimensi dan ataupun tiga dimensi ke dalam sebuah lingkungan nyata tiga dimensi lalu memproyeksikan benda-benda maya tersebut dalam waktu nyata. Selain menambahkan benda maya dalam lingkungan nyata, realitas tertambah juga berpotensi menghilangkan benda-benda yang sudah ada. Menambah sebuah lapisan gambar maya dimungkinkan untuk menghilangkan atau menyembunyikan lingkungan nyata dari pandangan pengguna [4].

AR merupakan teknologi yang melibatkan gambar grafis komputer dengan dunia nyata. Pengguna dapat melihat dunia nyata ditambah dengan benda-benda virtual dan dapat berinteraksi dengan lingkungan nyata. Dalam konteks yang lebih umum, AR juga disebut Mixed Reality yang mengacu pada spectrum multisumbu yang mencakup Virtual Reality (VR), Augmented Reality (AR), dan teknologi lainnya [5].

AR merupakan bentuk baru dari interaksi manusia dan mesin yang membawa pengalaman baru bagi penggunanya. Keutamaan yang dimiliki AR adalah AR dapat menimbulkan efek gambaran animasi komputer dalam dunia nyata [6]. Aplikasi AR menggunakan 
webcam yang akan mendeteksi marker yang telah dibuat dan menampilkan kombinasi antara gambar nyata dengan animasi [7]. Webcam digunakan sebagai mata dari teknologi AR untuk mendeteksi marker kemudian memprosesnya dan akan menghasilkan interaksi virtual yang tampak pada tampilan layar secara nyata [8].

C. Single Marker

Single marker atau yang dikenal sebagai satu penanda dalam augmented reality. Satu penanda dalam mendeteksi gambar yang dijadikan sebagai media marker dan hanya satu objek saja yang keluar, berbeda dengan multi marker yang dapat mendeteksi gambar yang dijadikan sebagai media marker dan banyak objek yang dapat keluar dalam satu waktu mendeteksi marker [9].

\section{Unity $3 D$ Engine}

Unity 3D Engine merupakan suatu software game engine yang terus berkembang saat ini. Keunggulan dari Unity $3 D$ Engine ini dapat menangani grafik dua dimensi dan tiga dimensi. Namun Unity $3 D$ Engine ini lebih konsentrasi pada pembuatan grafik tiga dimensi. Dari beberapa game engine yang sama-sama menangani grafik tiga dimensi, Unity $3 D$ Engine dapat menangani lebih banyak. Beberapa diantaranya yaitu Windows, MacOS X, iOS, PS3, wii, Xbox 360, dan Android yang lebih banyak daripada game engine lain seperti Source Engine, Game Maker, Unigine, id Tech 3 Engine, id Tech 4 Engine, Blender Game Engine, NeoEngine, Unity, Quake Engine, C4 Engine atau game engine lain. Unity $3 D$ Engine memiliki kerangka kerja (framework) lengkap untuk pengembangan profesional. Sistem inti engine ini menggunakan beberapa pilihan bahasa pemrograman, diantaranya C\#, javascript maupun boo [10].

\section{E. Vuforia}

Vuforia adalah Augmented Reality Software Development Kit (SDK) untuk perangkat mobile yang memungkinkan pembuatan aplikasi Augmented Reality. Dulunya dikenal dengan QCAR (Qualcomm Company Augmented Reality). Ini menggunakan teknologi Computer Vision untuk mengenali dan melacak gambar planar (target image) dan objek 3D sederhana, sepertu kotak secara real-time [11].

F. Perancangan Aplikasi

1. Flowchart Aplikasi

Flowchart aplikasi merupakan bagan alir dari menu utama aplikasi yang akan dibangun.

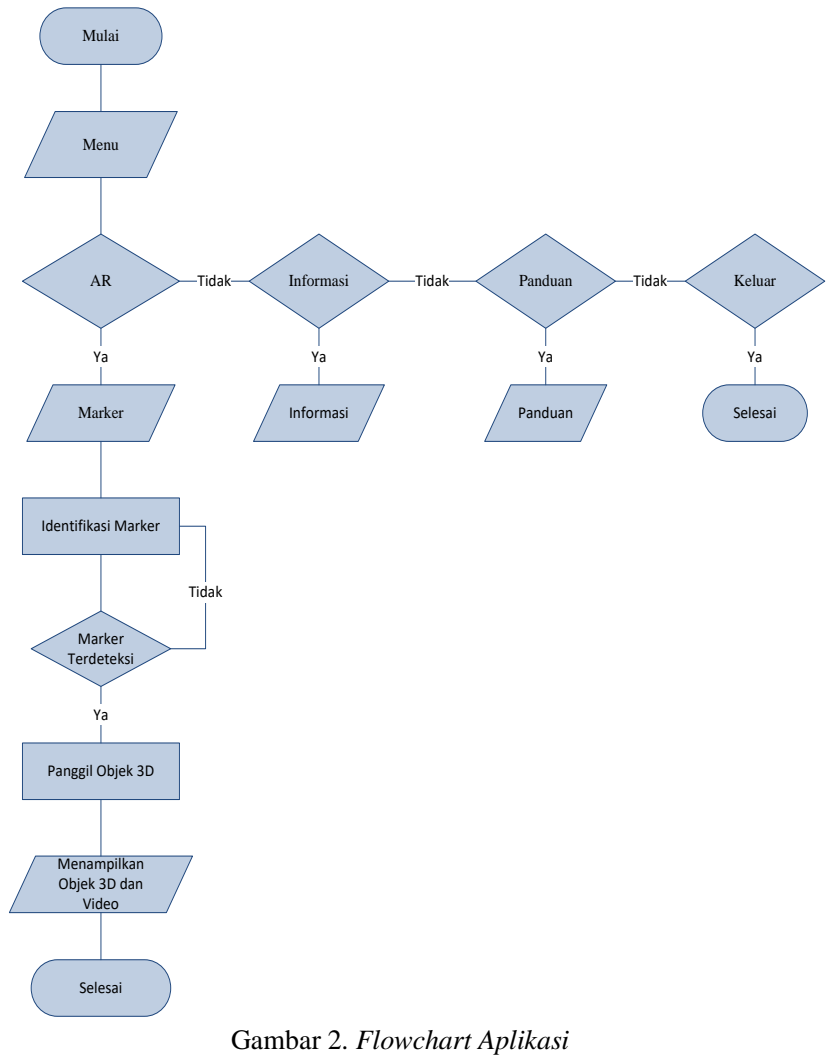

2. Single Marker

Single marker merupakan marker yang hanya menampilkan satu objek 3D dan tidak dapat membaca lebih dari satu marker. Cara kerja metode ini, image yang telah dibuat kemudian di-upload ke vuforia untuk dijadikan sebuah marker dan kemudian vuforia akan melakukan tracking image terhadap marker tersebut. 
Jurnal Pseudocode, Volume VII Nomor 1, Februari 2020, ISSN 2355-5920, e-ISSN 2655-1845 www.ejournal.unib.ac.id/index.php/pseudocode

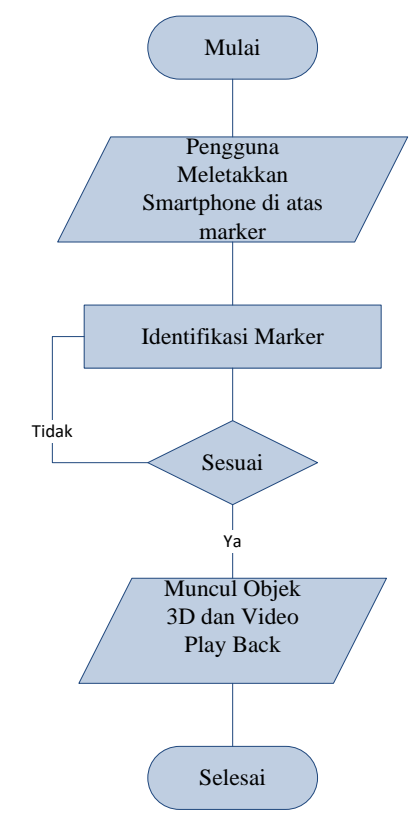

\section{b. Activity Diagram}

Berdasarkan use case diagram tersebut, maka dapat ditentukan activity diagram dari aplikasi pengenalan Bunga Rafflesia Arnoldi dan Bunga Bangkai menggunakan teknologi augmented reality berbasis Android.

Gambar 3. Flowchart Single Marker

\section{Unified Modeling Language (UML)}

a. Use Case Diagram

Diagram yang bekerja mendeskripsikan tipikal interaksi antara pengguna dengan sebuah sistem melalui sebuah cerita bagaimana sebuah sistem dipakai. Use case diagram terdiri dari sebuah aktor (user) dan interaksi yang dilakukannya
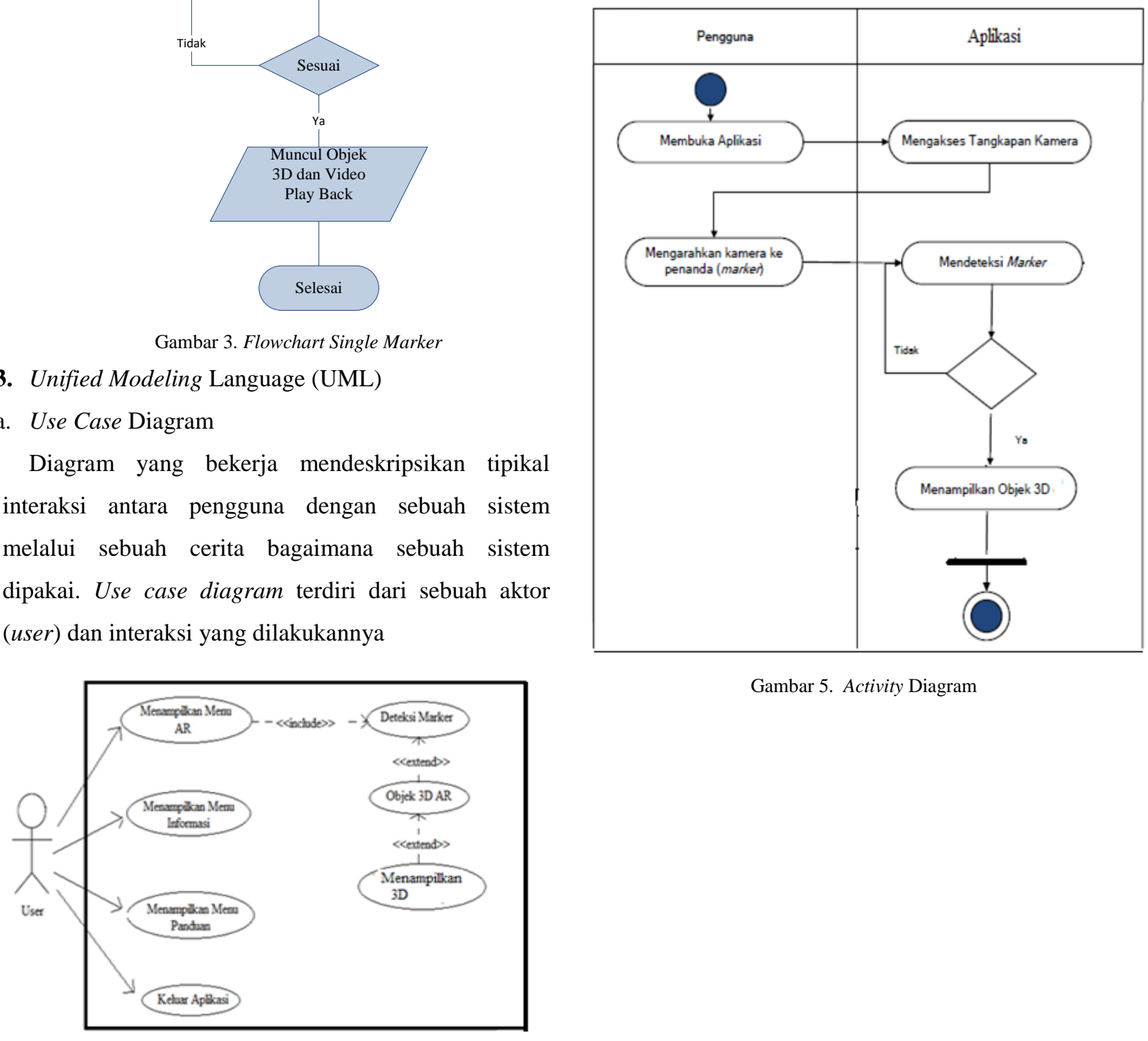

Gambar 5. Activity Diagram

Gambar 4. Use Case Diagram

\section{c. Sequence Diagram}

Sequence diagram menggambarkan interaksi antar objek. Interaksi antar objek berupa pengiriman data antar objek dalam urutan waktu. 


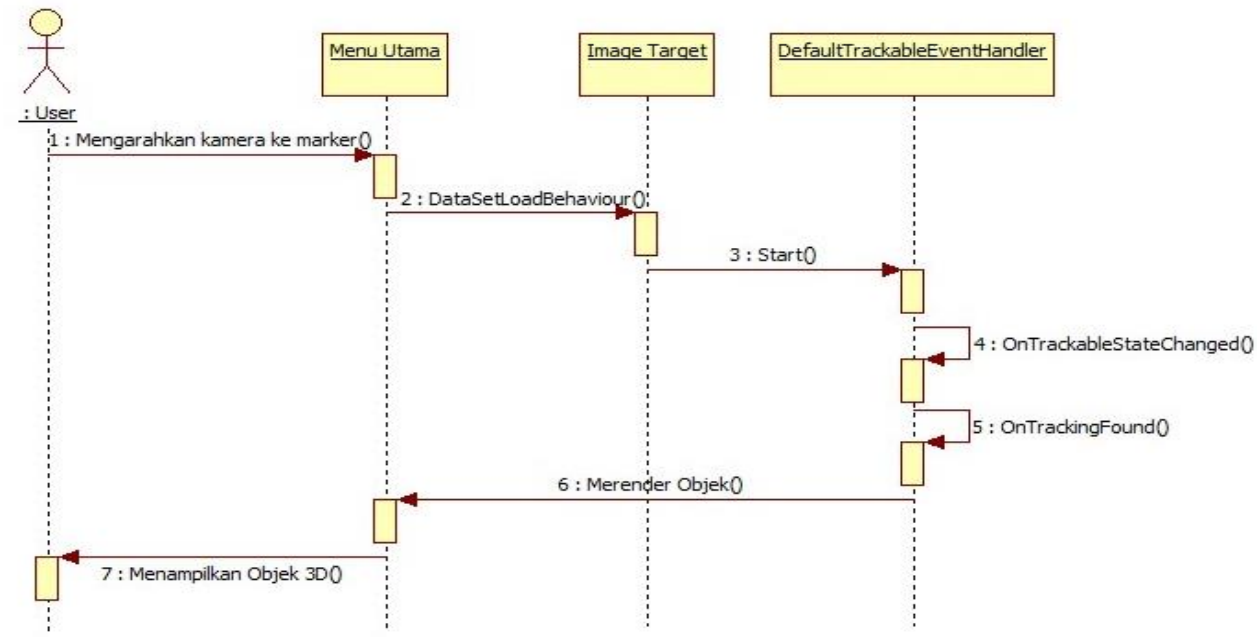

Gambar 6. Sequence Diagram

\section{d. Class Diagram}

Class diagram menggambarkan struktur dan hubungan antar objek-objek yang ada pada sistem. Struktur ini meliputi atribut-atribut dan metode-metode yang ada pada masing-masing kelas.

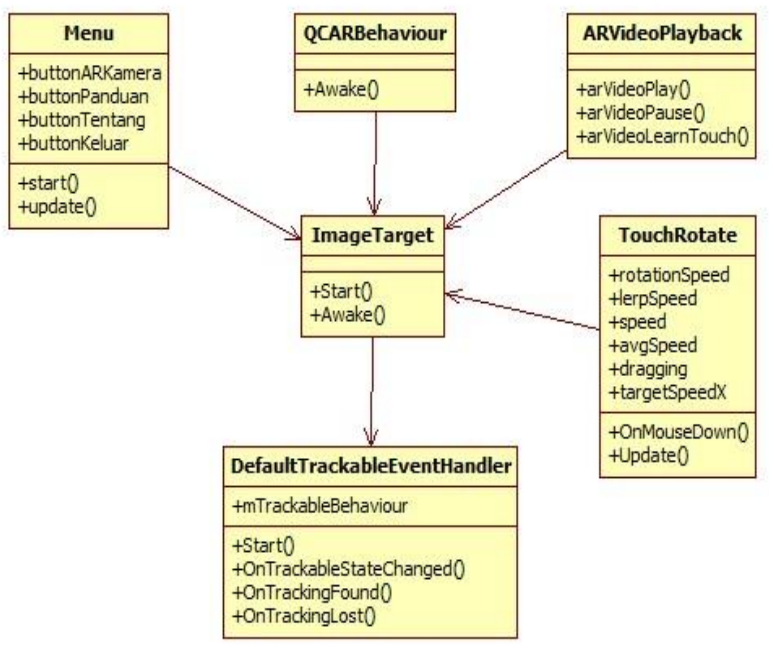

Gambar 7. Class Diagram

\section{Rancangan Tampilan Aplikasi}

Struktur menu Aplikasi Pengenalan Bunga Rafflesia Arnoldi dan Bunga Bangkai menggunakan teknologi augmented reality berbasis Android terdiri dari 4 menu, yaitu AR, Informasi, Panduan dan Keluar.

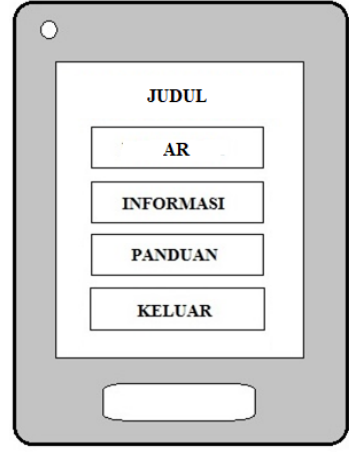

Gambar 8. Rancangan Tampilan Menu Utama Aplikasi

\section{Rancangan Tampilan Menu AR}

Menu AR digunakan untuk melihat gambar 3D dari Bunga Rafflesia Arnoldi dan Bunga Bangkai yang terdapat di Provinsi Bengkulu. Jika Menu AR dipilih, maka otomatis terhubung dengan kamera handphone. Kamera handphone yang telah hidup kita letakkan di atas marker AR yang telah dibuat sehingga muncul gambar 3D dari Bunga Rafflesia Arnoldi dan Bunga Bangkai tersebut.

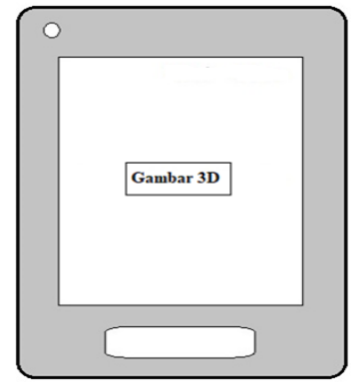

Gambar 9. Rancangan Tampilan Menu AR 
6. Rancangan Tampilan Menu Informasi

Menu Informasi berisi tentang informasi lengkap mengenai Bunga Rafflesia Arnoldi dan Bunga Bangkai yang terdapat di Provinsi Bengkulu.

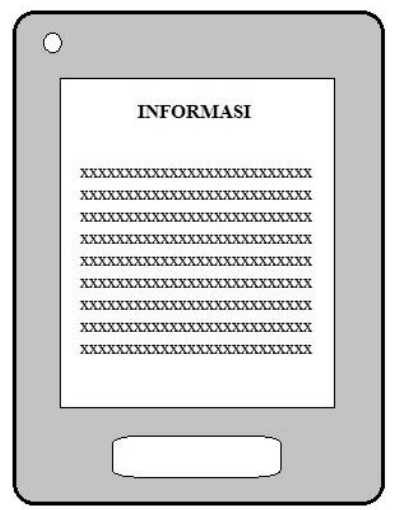

Gambar 10. Rancangan Tampilan Menu Informasi

7. Rancangan Tampilan Menu Panduan

Menu Panduan digunakan untuk bantuan kepada user dalam menggunakan aplikasi.

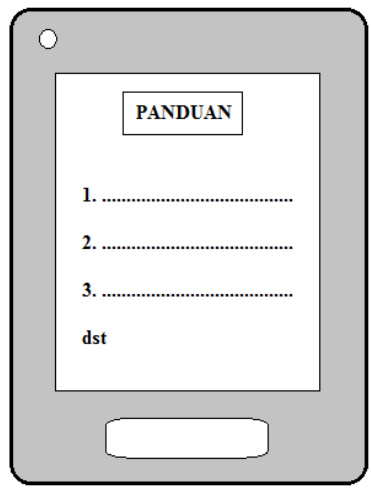

Gambar 11. Rancangan Tampilan Menu Panduan

\section{Rancangan Menu Keluar}

Menu Keluar digunakan untuk keluar dari aplikasi pengenalan Bunga Rafflesia Arnoldi dan Bunga Bangkai menggunakan teknologi augmented reality berbasis Android.

\section{G. Pengujian Sistem}

Parameter pengukuran yang digunakan untuk menganalisis aplikasi ini yaitu jarak dan pencahayaan. Pengujian dilakukan melalui dua tahap, yaitu pengujian black box dan pengujian marker. Pengujian black box dilakukan untuk mengecek apakah fungsi dari setiap tombol dan hasil eksekusi interface berhasil seperti yang diharapkan. Tahap pengujian marker terdiri dari beberapa skenario, diantaranya:

User melakukan scan marker dengan jarak $5 \mathrm{~cm}, 10 \mathrm{~cm}$, $30 \mathrm{~cm}, 50 \mathrm{~cm}, 100 \mathrm{~cm}$.

2. User melakukan scan marker dengan sudut kemiringan handphone $0^{\circ}, 45^{\circ}$ dan $90^{\circ}$.

3. User melakukan scan marker pada siang hari (pencahayaan matahari) dan malam hari (pencahayaan lampu, lampu dengan penghalang dan tanpa lampu).

\section{HASIL DAN PEMBAHASAN}

\section{H. Pembuatan Marker}

Marker adalah suatu penanda yang membuat objek 3D tampil pada tampilan kertas dilayar handphone. Untuk membuat marker dapat menggunakan aplikasi photoshop dan kita dapat membuatnya dari gambar yang ada.
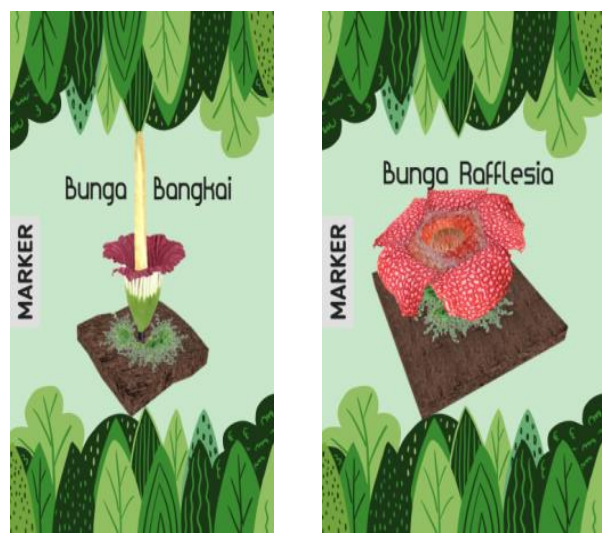

Gambar 12. Marker Bunga Khas Provinsi Bengkulu

\section{Implementasi Perancangan Antarmuka}

Perancangan antarmuka yang telah diterapkan berdasarkan sketsa yang dibuat pada bab 3 dapat dilihat pada gambar seperti berikut.

1. Tampilan menu utama aplikasi AR

Menu awal dari aplikasi AR terdiri dari empat pilihan menu, yaitu AR, Informasi, Panduan dan Keluar. 


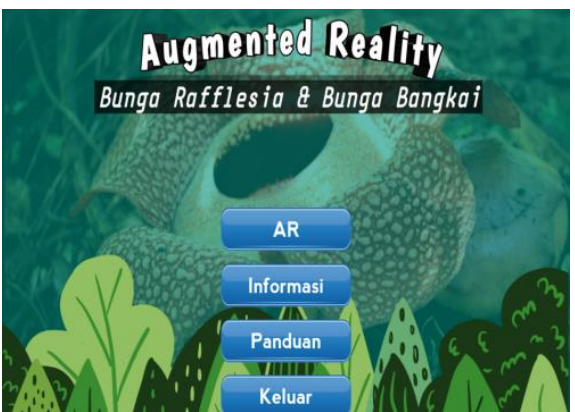

Gambar 13. Menu Utama Aplikasi

2. Menu AR

Menu AR digunakan untuk melihat gambar 3D dari bunga Rafflesia Arnoldi dan bunga Bangkai. Jika Menu AR dipilih, maka handphone akan langsung terhubung dengan kamera dan proses deteksi marker dapat dilakukan

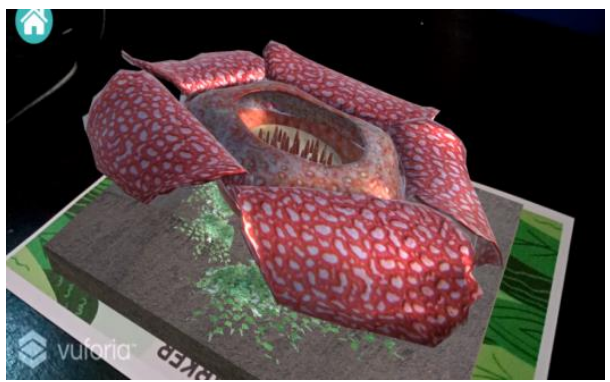

Gambar 14. Bunga Rafflesia Amoldi

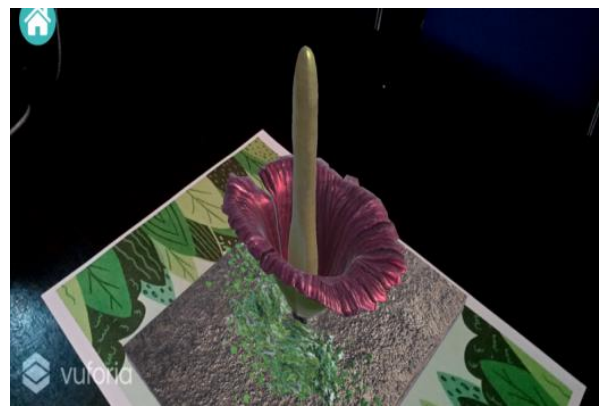

Gambar 15. Bunga Bangkai

3. Menu Informasi

Menu Informasi merupakan menu yang digunakan untuk mengetahui informasi tentang bunga Rafflesia Arnoldi dan bunga Bangkai.

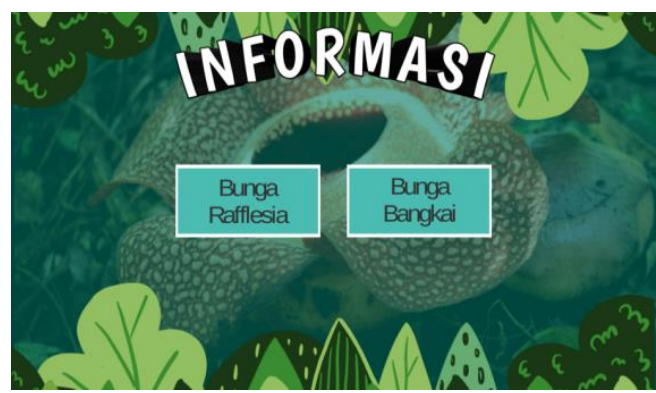

Gambar 16. Menu Informasi

4. Menu Panduan

Menu Panduan merupakan menu yang digunakan untuk mengetahui tata cara menggunakan aplikasi AR.

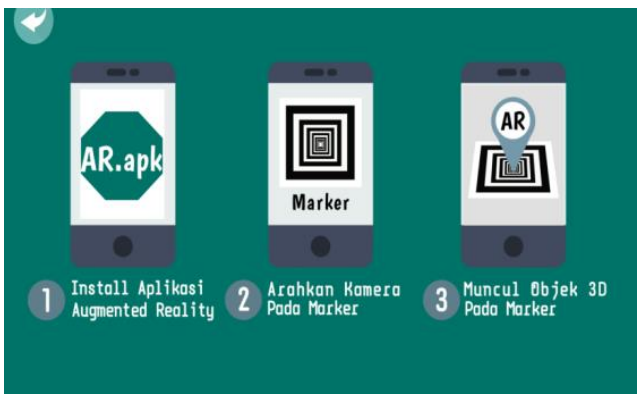

Gambar 17. Menu Panduan Aplikasi

5. Menu Keluar

Menu Keluar digunakan apabila pengguna ingin keluar dari aplikasi.

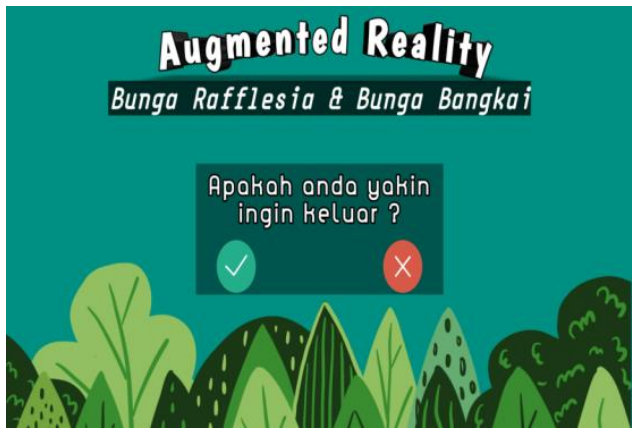

Gambar 18. Menu Keluar Aplikasi

\section{J. Pengujian}

Pengujian ini dilakukan untuk melihat apakah aplikasi AR yang telah dibuat berjalan sesuai dengan keinginan. Pengujian dilakukan terhadap marker dan fungsi yang terdapat pada aplikasi. Untuk pengujian marker dapat dilihat pada Tabel 1. sampai dengan Tabel 3. Pengujian fungsi menggunakan metode black box dapat dilihat pada Tabel 4. 
Jurnal Pseudocode, Volume VII Nomor 1, Februari 2020, ISSN 2355-5920, e-ISSN 2655-1845

www.ejournal.unib.ac.id/index.php/pseudocode

Tabel 1. Pengujian Jarak Kamera dengan Marker

\begin{tabular}{|c|l|}
\hline Jarak (cm) & \multicolumn{1}{|c|}{ Tingkat Keberhasilan } \\
\hline $5 \mathrm{~cm}$ & Muncul Gambar 3D \\
\hline $10 \mathrm{~cm}$ & Muncul Gambar 3D \\
\hline $30 \mathrm{~cm}$ & Muncul Gambar 3D \\
\hline $50 \mathrm{~cm}$ & Tidak Muncul Gambar 3D \\
\hline $100 \mathrm{~cm}$ & Tidak Muncul Gambar 3D \\
\hline
\end{tabular}

Tabel 2. Pengujian Pencahayaan

\begin{tabular}{|l|c|}
\hline \multicolumn{1}{|c|}{ Pencahayaan } & Tingkat Keberhasilan \\
\hline Siang hari (matahari) & Muncul Gambar 3D \\
\hline Malam hari (lampu) & Muncul Gambar 3D \\
\hline $\begin{array}{l}\text { Malam hari (lampu dengan } \\
\text { penghalang) }\end{array}$ & Muncul Gambar 3D \\
\hline Malam hari (tanpa lampu) & Tidak Muncul Gambar 3D \\
\hline
\end{tabular}

Tabel 3. Pengujian Sudut Kemiringan Kamera dengan Marker

\begin{tabular}{|c|c|}
\hline Sudut Kemiringan & Tingkat Keberhasilan \\
\hline $0^{0}$ & Muncul Gambar 3D \\
\hline $45^{0}$ & Muncul Gambar 3D \\
\hline $90^{0}$ & Tidak Muncul Gambar 3D \\
\hline
\end{tabular}

Tabel 4. Pengujian Black Box

\begin{tabular}{|l|c|}
\hline \multicolumn{1}{|c|}{ Menu } & Tingkat Keberhasilan \\
\hline Menu AR & Muncul Gambar 3D \\
\hline Menu Informasi & Muncul Gambar 3D \\
\hline Menu Panduan & Muncul Gambar 3D \\
\hline Menu Keluar & Muncul Gambar 3D \\
\hline Kamera & Muncul Gambar 3D \\
\hline Tombol Home & Muncul Gambar 3D \\
\hline Tombol Back & Muncul Gambar 3D \\
\hline
\end{tabular}

\section{KESIMPULAN DAN SARAN}

\section{A. Kesimpulan}

Dari penelitian yang telah dilakukan, didapatkan beberapa kesimpulan yang dapat diambil dari proses pembuatan aplikasi pengenalan bunga khas Provinsi Bengkulu yang memanfaatkan teknologi augmented reality, antara lain:

1. Objek tiga dimensi dapat divisualisasikan dalam perangkat handphone saat kamera mendeteksi kertas gambar yang telah dijadikan sebagai marker.

2. Jarak pada saat proses tracking ke marker sangat mempengaruhi muncul tidaknya sebuah objek 3D. Jarak yang diperlukan agar marker terdeteksi oleh sistem adalah pada rentang jarak $20 \mathrm{~cm}$ sampai dengan $40 \mathrm{~cm}$. Diluar dari rentang jarak tersebut maka sistem tidak dapatmendeteksi marker sehingga objek 3D tidak akan muncul.

3. Cahaya sangat mempengaruhi dalam proses mendeteksi marker. Semakin bagus intensitas cahaya yang didapatkan maka sistemakan semakin cepat dalam mengenali marker dan sebaliknya Ketika tidak terdapat cahaya maka sistem tidak dapat mendeteksi marker.

B. Saran

Saran yang dapat diberikan untuk penelitian yang memanfatkan teknologi augmented reality lebih lanjut adalah:

1. Menggunakan metode lain selain single marker seperti markerless(tanpa marker).

2. Melakukan penambahan audio atau bahkan video.

3. Penambahan pergerakkan objek menggunakan touch.

\section{REFERENSI}

[1]. Susatya A. 2011. Rafflesia Pesona Bunga Terbesari di Dunia. Cetakan I. Direktorat Kawasan Konservasi dan Bina Hutan Lindung.

[2]. Azuma RT. 1997. A survey of Augmented Reality. In Presence: Teleoperators and Virtual Environment 6: 355-385.

[3]. Sukamto, R. A., and M. Shalahudin Rekayasa Perangkat Lunak. "Bandung." Informatika (2016).

[4]. Andriyadi A. 2011. Augmented Reality With ARToolkit Reality Leaves a lot to Imagine. Lampung. Augmented Reality Team.

[5]. Toan P, Viet, Yeon C, Seung. 2010. Interior Design in Augmented Reality Environment. http://www.ijcaonline.org/volume5/number5/pxc3871290.pdf. Diakses tanggal 5 Maret 2019.

[6]. Michael RL, IrwinKing TTW, Edward Y dan Chan PW. 2005. ARCADE: Augmented Reality Computing Arena for Digital Environment.

[7]. Cholifah C, Ardilla F dan Hakkum RY. 2010. Rubber Ball Virtual Game dengan menggunakan ARToolkit (Augmented Reality Toolkit).

[8]. Rahman GR dan Thalib F. 2011. Pengembangan Teknologi Augmented Reality sebagai Penunjang Industri Musik Indonesia.

[9]. Roedavan R. 2014. Unity Tutorial Game Engine.Yogyakarta. Scott W.A. 2005. The Elements of UML.Hal: 33.

[10]. Remondino AM. 2012. A review of Reality-Based 3D Model Generation, Segmentation and Web-Bassed Visualization Methods.

[11]. Rentor MF. 2013. Membuat Aplikasi Augmented Reality Menggunakan Vuforia SDK dan Unity. Yogyakarta. Universitas Atma Jaya Yogyakarta. 